\title{
THE STRATEGY OF LOCAL FOOD MARKETING AND DEVELOPMENT AS A TYPICAL SOUVENIR OF DAIRI REGENCY
}

\begin{tabular}{|c|c|c|}
\hline Ngatemin & Abdul Kadir Ritonga & Trisnawaty \\
Medan Tourism Polytechnic & Medan Tourism Polytechnic & Medan Tourism Polytechnic \\
Medan, Indonesia & Medan, Indonesia & Medan,Indonesia \\
ngnngatemin@gmail.com & ritonga07abk@yahoo.co.uk & trisnawaty.mdn@gmai.com \\
\hline
\end{tabular}

\section{ABSTRACT}

This study aims to analyze the strategy of local food marketing development as a typical souvenir of Dairi Regency. The data in this study is taken from the population of the restaurant manager and the community engaged in the culinary field by random sampling. Population amounted to 100 and the total sample of respondents was 60 people after random sampling. The research method is a descriptive analysis research method using SWOT analysis. The formulation of the problem of this research is 1) How is the readiness of the community in preparing local food as a typical souvenir of Dairi Regency? 2) How is the prospect of local food industry business as a typical souvenir of Dairi Regency? 3) How is the economic impact for the community in preparing local food as a typical souvenir of Dairi Regency? The results show that 1) the community is not ready to develop the marketing of local food as a typical souvenir of Dairi Regency, 2) The community does not understand the prospects of the local food industry as a typical souvenir of Dairi Regency, 3) The public has not felt the economic impact in preparing local food as a typical souvenir of Dairi Regency.

Keywords: Local food, Marketing and Development Strategy, Souvenir

\section{INTRODUCTION}

Dairi Regency is one of 33 districts / cities in North Sumatra Province with an area of 192,780 hectares. This regency occupies about $2.69 \%$ of the area of North Sumatra Province $(7,160,000$ hectares) located in the northwest of North Sumatra Province. The regency is located at an average altitude of 700 s.d. $1,250 \mathrm{~m}$ above sea level so that most of the weather is cool and tends to be cold at night, Dairi regency consists of 15 subdistricts among others: Berampu District, Gunung Sitember, Lae Parira, Parbuluan, Pegagan Hilir, Sidikalang, Siempat Nempu, Siempat Nempu Hilir,
Siempat Nempu Hulu, Silahisabungan, Silima PunggaPungga, Sitinjo, Sumbul, Tanah Pinem, Tigalingga.

As a tourist destination, Dairi Regency has several tourist objects and attractions that are very attractive to tourists, both natural and artificial ones. Some objects and tourist attraction data that can be enjoyed in Dairi Regency are:

a. Lae Renun River

b. Panorama of Sidiangkat Peak

c. Lae Pondom Tourism Forest.

d. Silalahi Sabungan Beach Tourism

e. Pakpak Traditional House

f. Lae Baski Waterfall

g. Waterfall and Lake Sicike-Cike.

h. Panorama Letter "S" and the city of Sumbul

i. Faith Tourism Park of Sitinjo

j. Lae Pendaroh Waterfall

Types of Local / Traditional Food

The types of local food consumed by people in Dairi Regency include:

1. Pelleng. Dairi is a traditional food in the form of yellow rice which is usually used as traditional food as a spirit picker or as a sign of gratitude for something that has been achieved by someone or a family (as well as Tumpeng in Javanese tribes).

2. Nakan Merasa or Nakan Pagit, is a traditional / local food whose ingredients are rice mixed with bungke (fruit from plants that taste bitter, inggiringgir [Toba] singgaren (fragrant plants), rimbang, and eggplant. This meal is usually served on pickles 5 to 7 months of pregnancy First, a mother, who feels that she wants to feel or want to be sick, is intended to get pregnant women to get strength so that they can avoid all kinds of diseases.

3. Nditak Dabur, is a snack food made from rice flour mixed with coconut and brown sugar. This snack food is usually consumed in the morning as breakfast food or evening as a complementary food to drink coffee or tea. 
4. Ginaru Ncor. This food is a dish in the form of rice porridge cooked with Pak-pak's special spices and various other spices. To make the Ginaru Ncor is not like making ordinary rice porridge because before it is cooked as rice porridge it must be ground or ground first so that the resulting porridge will become very soft. For spices such as lemongrass, bay leaves and cikala acid do not need to be smoothed. Simply mashed and then sauteed, this is done so that the spices do not dissolve in the spices, because the spices are only as a complement.

5. Nakan Nggersing. Nakan nggersing is a special food for the Pakpak tribe, this food is usually used in traditional ceremonies that have a relationship with agriculture or choose (reject the reinforcement). Nakan Nggersing consists of mening rice (cut into rice), vegetables, among others; pumpkin leaves (bulung roroh), pariah leaves, spinach, leuh, sweet potato leaves (gadong jolor), young long bean leaves, pumpkin flowers, small pumpkin fruit, smells, kumange, garanggarang and tomato kampung (randat ) Sometimes added with wood fruit called ntarsa, it is also mixed with chicken sliced in small pieces and petai. Usually rice is cooked with turmeric, and the side dish is boiled eggs.

The existence of some of these tourism objects makes Dairi Regency currently become one of the destinations that are crowded with tourists, and various local culinary delights are a positive prospect for the improvement of the economy of the tourism sector, especially those of micro, small and medium enterprises (MSMEs). Increasing tourist visits will have an impact on several other sectors (multipplier effect). The small and medium business sector (UKM) is the sector that has benefited most from the development of the tourism sector. Followed by the accounting sector including culinary. Culinary developments with various innovations will greatly support the growth of tourism in an area. The availability of clean and hygienic culinary will guarantee consumers a safe feeling to consume it.

One of the needs of tourists visiting tourist destinations is the need to eat and drink or culinary. Food and beverages as a tourist need will be an important factor for the comfort of tourists therefore their availability must be of particular concern to tour operators in the destination. Food and beverages that are guaranteed to be clean will be a health guarantee for tourists. Local / traditional food will also be a separate icon if found in the destination. In terms of destination development, one of the things that needs to be developed is the local food product. So that if tourists visit the destination it will be a special memory. Culinary products can also be a gift (souvenir) for tourists must be practical, affordable, and easy to carry.

Dairi Regency, which is the majority of the population, is the Pak-Pak tribe, which has local / traditional foods in the form of: Pelleng (yellow rice),
Nakan feels / feels, nditak, Ginaru, Ikan Lae, Gettuk, Lappet and so on. Some of these traditional foods are currently less well known by guests who visit this area due to lack of promotion or publication. On the other hand these food products from packaging still do not have an attractive and efficient presentation standard, so they lack good market share for consumers. Apart from that among the traditional meals there are some of them are traditional foods (including pelleng) so that in the presentation they should not be careless and must follow customary norms which are generally only understood by the elderly.

\section{Research Hypothesis Testing}

Based on the background of the research above, the formulation of the problem can be formulated as follows:

1. How is the readiness of the community in preparing local food as a typical gift of Dairi Regency to support the development of tourist destinations in Dairi Regency

2. How is the business prospect of the local food industry as a typical gift of Dairi Regency to support the development of tourist destinations in Dairi Regency

3. What is the economic impact for the community from the local food industry business as a typical gift in Dairi District.

\section{LITERATURE REVIEW}

Local / traditional food is a typical food product which is usually only available in the area and is a traditional food of ancestral heritage that has been consumed for generations by the people in the area. Every tribe in Indonesia has a unique and diverse traditional food. According to Kuhnlein and Receveur in Kwik (2008) Traditional food systems of indigenous peoples can be defined to items that are from the local, natural environment that is culturally acceptable. It also includes the sociocultural meanings, acquisition / processing techniques, use, composition, and nutritional consequences for the people using the food. On the other hand, according to the department of local food agriculture which is also referred to as local food which is defined as food produced locally (one region / region) for economic purposes and or consumption whose biological origin is found in an area (http: //www.deptan .go.id)

The diversity of traditional foods arises because of the diversity of ingredients, how to cook / process them, the way they are presented and because of their use or function. Local / traditional foods are generally consumed by specific ethnicities and regions, processed from recipes known to the public, the ingredients are obtained from local sources and have a taste that is relatively in accordance with the tastes of the local community. In addition, traditional foods are generally cultural flavored products which are a combination of the creation of local resource processing with the taste of traditional spices and has been passed down from generation to generation. Therefore traditional food generally has its own advantages in the form of; 
processed from fresh and natural ingredients. The fat content is relatively low, does not use additives (coloring and preservatives), is relatively safe for health, in accordance with tastes and habits, relatively low cost, affordable prices and very varied (Komariyah: 2010). Besides that, from the perspective of traditional food tourism in an area it can be a memory and a special gift for tourists as a reminder that tourists have visited the area, so traditional food has great potential to develop its marketing.

The amount of potential and strategic value of local food products to be marketed is based on:

a. Indonesian people generally have a culture of bringing souvenirs (souvenirs) when visiting relatives or relatives and local food is one of the options for this.

b. The culture that developed in Indonesian society has placed souvenirs as a necessity for those who travel to an area or those who return from the area.

c. Optimizing the local / traditional food industry can be a means of promotion and representation of local culture as well as preservation of national culture

d. The impact of increasing local / traditional food marketing is the populist economy dominated by micro, small and medium enterprises (MSMEs) which in turn will affect the welfare of local / traditional food producers and sellers.

According to Rahmady and Andi (2007: 1), the strategy is a unified, broad and integrated plan that links the superiority of corporate strategy with environmental challenges and is designed to ensure that company objectives can be achieved through proper implementation by the organization. Strategies are usually carried out in certain circumstances, such as winning the competition, controlling the market and so on. To be able to implement the strategy that has been set, management is needed for the strategy. While the strategy management itself can be defined as art and knowledge in formulating, implementing, and evaluating cross-functional decisions that enable an organization to achieve its goals (David, 2010: 5).Furthermore, strategic management according to Rahmady and Andi (2007: 1), is a managerial action that tries to develop the potential of the company in exploiting business opportunities that arise in order to achieve the company's objectives.

In general, companies occupy different competing positions in competitive positions, there are several strategies that can be applied, namely:

a. Market Leader Strategy. The market leader strategy is a company that is recognized by the relevant leader. The characteristic of the market leader is to have the largest market share in the relevant product market. The advantages of this company are in terms of new product introduction, price changes, distribution channel coverage and promotion intensity. In companies that enter the market leader strategy, companies always want to be number one. This attitude encourages developing the market as a whole, protecting the market, and expanding market share.

b. Market Challenger Strategy. The market challenger strategy is the number two company that constantly tries to enlarge their market share, which in the business they face openly and directly with the market leader. Characteristics of market challengers are usually seen from the point of view of sales volume and profit and try to find weaknesses in the market leader or other companies. And then attack him both directly and indirectly. There are two main things that need to be carefully planned by the market challenger, namely determining the opponent and the target of the strategy and choosing an attack strategy.

c. Market Followers Strategy (Market Follower). Market follower strategy is a company that takes an attitude that does not disturb market leaders and is only satisfied by adjusting to market conditions. Companies that use market follower strategies also need to formulate strategies for growth and try not to invite replies from other companies.

d. Market Nicher Strategy. The strategy of cultivating market niches is a strategy whereby companies that specialize in serving part of the market are ignored by scale and avoid forms of attack with other companies.

In addition, according to Rangkuti (2001: 6), in principle, strategies can be grouped based on three types of strategies, namely:

1. The management strategy includes strategies that can be carried out by management with a strategy development orientation at a macro level such as product development strategies, pricing strategies, acquisition strategies, market development strategies and financial strategies, and so on.

2. Investment strategy is an investment-oriented activity such as whether the company carries out an aggressive growth strategy or seeks to establish market penetration, defensive strategies, strategies for rebuilding a new division or divestment strategy, and so on.

3. Business strategy is often called a functional business strategy because this strategy is oriented to the functions of management activities such as marketing strategies, production or operational strategies, distribution strategies, organizational strategies, and financial-related strategies.

Marketing is inseparable from four marketing mixes that are often known with $4 \mathrm{P}$, namely Product, Price, Promotion, and Place. According to Kotler and Armstrong (2008: 62-63) the marketing mix covers:

a. Product. The product is a combination of goods / services offered by the company to the target market.

b. Price. Price is the amount of money the customer must pay to get the product / service. 
c. Distribution or Place. Places include company activities that make products / services available to target customers.

d. Promotion. Promotion is an activity that conveys the benefits of products / services and persuades customers to buy them.

Marketing strategy is the determination of the direction of marketing of a product) so as to be able to create sustainable demand, corporate profits and company development in the long term. In running a business, it is important for business people to pay attention to these four things and determine the most prioritized factors of each marketing mix as their marketing development strategy. Marketing is one of the main activities carried out by the company to face competition and maintain the viability of its business so that it can continue to grow and earn profits in accordance with the wishes of the company. Marketing is a social and managerial process in which individuals or organizations get what they need and want through the creation and exchange of values with others (Kotler and Armstrong, 2008: 6).

Marketing mix is the main element in the marketing strategy which consists of four variables namely product, price, promotion, and distribution system which is a core of the marketing system in the company. Marketing mix is a tool to plan, implement, and regulate the main marketing goals and strategies of an organization. The application of the marketing mix as a marketing tool and function is emphasized to exchange value which is something that is needed by certain parties and the sacrifice needed for the analysis is based on the theory of marketing strategy, specifically the marketing mix strategy which includes; 1) Productoriented strategies 2) Price-oriented strategies 3) Distribution-oriented strategies. 4) Strategies that are oriented towards promotional activities.

Local / traditional food products are processed products derived from agricultural commodities (agriculture in the broad sense) generally have distinctive characteristics, including: easily damaged and not durable, produced based on the availability of raw materials, large volume but nominal value relatively small, and specific localities (cannot be produced in all places). Therefore, prices often occur uncertain local / traditional food production, fluctuating, and non-standard between locations with one another. This has an adverse effect on the producer therefore it requires insight into marketing knowledge, both partially and in groups in order to increase the strength (bargaining power) to carry out the marketing of the product.

According to Philip Kotler (1980) there are 5 factors why marketing is important, namely; An indication of the number of products being marketed is decreasing, an indication of the need to improve the marketing mechanism or strategy. Especially if the profit level of producers (companies) also decreases, the producers (marketing managers) must immediately improve their marketing strategies. But keep in mind that product marketing strategies can also change, if consumer wants also change. Changes in consumer desires can occur due to changes the level of income, so the preference for a local / traditional food product also changes.

According to Clarke J \& Godfrey K. (2000) Realistic "Goals and Objectives" are the core for successful tourism development. The Tourism Action Steps concern who, what, where and how to explain how goals and objectives will be implemented. Tourism actions state what will be done, when will it be done and by whom. The Tourism Action Steps must be clear and have a specified time period and expected goals. According to Godfrey and Clarke (2000) the process of forming a tourism strategy consists of three steps, namely:

a. Identifying Opportunities and Constraints (Based on an evacuation of supply and demand).

b. Goals and Objective setting development (addressing issues in short, medium and longer terms).

c. Define a series of action steps (Designed to achieve goals and objectives within a specified time frame).

A destination can be said to be doing tourism development if previously there are tourist activities. To be able to increase tourism potential, what needs to be done is to plan tourism development so that it can be better than before. Three main principles in sustainability development (McIntyre, 1993: 10):

1. Ecological Sustainability, which ensures that the development carried out is in accordance with the ecological, biological, and diversity processes of existing ecological resources.

2. Social and Cultural Sustainability, which ensures that the development carried out has a positive impact on the lives of the surrounding community and in accordance with the culture and values that apply to the community.

\section{RESEARCH METHODOLOGY}

Population is a generalization area which consists of objects / subjects that have certain characteristic qualities determined by researchers to be studied and then drawn conclusions (Sugiyono, 2002). In this study, the population is people living in Dairi Regency, especially those related to the production and marketing of Dairi's typical local / traditional foods and experts / consumers of local / traditional food in Dairi Regency. Because of the locus area and time limitation, samples were taken randomly. Data colected from respondent by observation, literature, quesionanire, and interview. This research is a survey research, where research is carried out directly or field research with data retrieval directly to respondents (data pimer) where information is obtained from respondents collected empirically to obtain opinions from some populations on the object of research. Based on the type of data and analysis, the design of this study is a combination of quantitative research data and qualitative data. The collected data will then be tabulated and then analyzed by SWOT analysis, then it will be concluded that the most effective combination of SWOT analysis is applied at 
the research locus. SWOT Analysis (StrenghtsWeaknesses-Opportunities-Threats) is a tool used to identify various factors systematically to formulate a marketing strategy (Hidayat, Maceilla: 2011)

Internal environment analysis is useful for knowing strengths and weaknesses, while external environmental analysis is useful for knowing opportunities and threats in marketing their products. The information obtained is then made in the IFE matrix and EFE matrix. Furthermore, the two matrices are combined in the IE matrix that is used to determine the current position of the company and get the core strategy of the company, then use the SWOT matrix to determine some alternative strategies that the company will do so that marketing activities can provide maximum results. The last stage is the decision making stage or the selection of the most appropriate strategy by using the QSPM matrix which functions to determine the best priority marketing strategy that should be used by the company.

\section{Research Results}

\section{FINDINGS AND RESULTS}

The number of respondents in this study were 100 people consisting of 30 people and culinary business managers and represented 70 consumers and experts. The selection of respondents was done randomly with a random sampling method. Of the 8 questions submitted to respondents can be described as follows.

Table 1. Local / traditional food products marketed favored by consumers

\begin{tabular}{clllr}
\multicolumn{5}{c}{$\mathrm{n}=60$} \\
\hline No. & \multicolumn{1}{c}{ Question } & Amount & $\%$ \\
\hline 1 & $\begin{array}{l}\text { Are local / traditional food } \\
\text { products that Mr / } \\
\text { markets are popular } \\
\text { consumers }\end{array}$ & & & \\
& & & & \\
a. Yes & & 50 & 83 \\
& b. No & 10 & 17 \\
\hline & & 60 & 100 \\
\hline
\end{tabular}

Source: Processed Data Results 2017

From the table 1, it can be explained that the community and culinary business managers tend to say yes $(83 \%)$ shows that local / traditional food products still have a good market share. Furthermore, to find out the response of local / traditional food producers / traders to product variations can be seen in table 2 :

Table 2. Product Variations Local/traditional food products

$$
\mathrm{n}=60
$$

\begin{tabular}{clrr}
\hline No. & \multicolumn{1}{c}{ Question } & Amount & $\%$ \\
\hline 2 & Whether local / traditional & & \\
food products produced have & & \\
variations in both form and & & \\
flavor. & & \\
a. Yes & 8 & 13 \\
b. No & 52 & 87 \\
\hline Total & 60 & 100 \\
\hline
\end{tabular}

Source: Processed Data Results 2017
From the table it can be explained that respondents tend to state that there is no variation in product and flavor $(83 \%)$. This shows that local / traditional food products do not have a variety that varies in form and taste.

Table 3. Promotional Activities Local/traditional food products

\begin{tabular}{clrr}
\multicolumn{3}{c}{$\mathrm{n}=60$} & \\
\hline No. & \multicolumn{1}{c}{ Question } & Amount & $\%$ \\
\hline 3 & Do the local / traditional & & \\
& food products produced have \\
& promotional activities & & \\
& a. Yes & 48 & 80 \\
& & & \\
b. No & 12 & 20 \\
\hline & Total & 60 & 100 \\
\hline
\end{tabular}

Source: Processed Data Results 2017

From the table it can be explained that respondents tend to state that there are no promotional activities for local / traditional food products $(80 \%)$. This shows that local / traditional food products do not have promotional activities in their marketing activities.

Table 4 Product Marketing Limited local / traditional food products

$$
\mathrm{n}=60
$$

\begin{tabular}{clrr}
\hline No. & \multicolumn{1}{c}{ Question } & Amount & $\%$ \\
\hline 4 & $\begin{array}{l}\text { Are local / traditional food } \\
\text { products produced in limited } \\
\text { areas }\end{array}$ & & \\
& & & \\
a. Yes & 50 & 83 \\
& b. No & 10 & 17 \\
\hline & Total & 60 & 100 \\
\hline
\end{tabular}

Source: Processed Data Results 2017

From the table it can be explained that respondents tend to state that product marketing is still in a limited area $(83 \%)$ This shows that local / traditional food products are still marketed in a limited area.

Table 5. Production Capacity of local / traditional food products

$$
n=60
$$

\begin{tabular}{clrr}
\hline No. & \multicolumn{1}{c}{ Question } & Amount & $\%$ \\
\hline 5 & Is the capacity of local & & \\
& traditional foog production & & \\
& limited? & & \\
& a. Yes & 44 & 73 \\
& & 16 & 27 \\
b. No & 60 & 100 \\
\hline
\end{tabular}

Source: Processed Data Results 2017

From the table it can be explained that in general local / traditional food production capacity is still limited $(73 \%)$ This shows that local / traditional food products have limited production capacity because they are still traditionally cultivated.

Table 6. Local / traditional food product production facilities

$$
\mathrm{n}=60
$$




\begin{tabular}{clrr}
\hline No. & \multicolumn{1}{c}{ Question } & Amount & $\%$ \\
\hline 6 & $\begin{array}{l}\text { Does the business that you } \\
\text { do still have operational }\end{array}$ & & \\
facilities and infrastructure & & \\
that are still lacking / & & \\
inadequate? & 42 & 70 \\
a. Yes & 18 & 30 \\
b. No & 60 & 100 \\
\hline Total & & \\
\hline Source: Processed Data Results 2017 & &
\end{tabular}

Source: Processed Data Results 2017

From the table it can be explained that respondents tend to state that the facilities and infrastructure of local / traditional food products are still limited / limited $(70 \%)$ This shows that local / traditional food products lack adequate facilities and infrastructure in their production activities.

Table 7. Local / traditional food product venture capital

$$
n=60
$$

\begin{tabular}{clrr}
\hline No. & \multicolumn{1}{c}{ Question } & Amount & $\%$ \\
\hline 7 & $\begin{array}{l}\text { Does the business that you } \\
\text { do still have limited business }\end{array}$ & & \\
& capital? & & \\
a. Yes & 40 & 67 \\
& 20 & 33 \\
\hline b. No & 60 & 100 \\
\hline
\end{tabular}

Source: Processed Data Results 2017

From the table it can be explained that respondents tend to state that business capital for local / traditional food products is still limited $(60 \%)$ but some have adequate capital $(37 \%)$. This shows that the business capital of local / traditional food products is still limited but a small portion already has sufficient business capital. Next to find out how the respondent's response to the management system applied by Dairi local / traditional food entrepreneurs can be seen in table 4.8 below:

Table 8. Local / traditional food product management system

$$
\mathrm{n}=60
$$

\begin{tabular}{clrr}
\hline No. & Question & Amount & $\%$ \\
\hline 8 & Does the business that you & & \\
do still have a traditional & & \\
management system & & \\
a. Yes & 27 & 90 \\
b. No & 33 & 10 \\
\hline Total & 60 & 100 \\
\hline
\end{tabular}

Source: Processed Data Results 2017

From the table it can be explained that respondents tend to state that the management of the production of local / traditional food products is still traditional (90\%). This shows that local / traditional food products are less still using traditional management or family management.

This study uses SWOT analysis techniques, namely analysis to find strengths, weaknesses, opportunities and threats to products, markets, policies and marketing programs. SWOT analysis is used to analyze how strengths, weaknesses, opportunities, opportunities that are owned by local / traditional food product processing businesses in Dairi Regency. The results of the identification of SWOT are then formulated a combination strategy that can be carried out can be used as a solution to the existing conditions.

From the results of the collection and processing of empirical data obtained from the respondents, the discussion can be explained in the discussion that local / traditional food products tend to be favored by consumers, even though more fans are from the adult age group. Furthermore, in terms of product variations both the shape and taste are still very minimal so that future innovation is needed for the product. Meanwhile, in terms of promotion for local / traditional food products, it is still less promoted, both direct promotion through advertisements in print and electronic media. Publication for these products is still in the form of reviews on internet media through personal blogs or tourism institutions in cyberspace.

In terms of marketing, local / traditional food products produced are limited in areas that are limited, and even more can be said that marketing is still in the form of orders or catering from producers / sellers to consumers. Whereas for its own production from local / traditional food is generally produced in limited quantities, because these foods are generally only consumed in traditional events such as graduation / success thanksgiving to get something, pick up spirits and so on. On the other hand, producers who produce local / traditional food products also generally still use simple facilities and infrastructure and are still in the form of a home industry so that if there are orders in large quantities, the production facilities and infrastructure are inadequate. Besides that, in terms of capital because the continuity of production is still not guaranteed, entrepreneurs still use limited capital. While for the management system generally still use traditional systems and not with more modern / professional patterns.

The results of the survey and field observations of local / traditional food product businesses in Dairi Regency, especially in Sidikalang City as the district capital, obtained the identification of several things related to local / traditional food businesses as follows:

\section{Internal Factor}

Internal factors are those that come from local / traditional food product businesses. This factor will be a strength or weakness (Weakness) for local / traditional food product processing businesses in Dairi Regency. Some of these internal factors are strength / Strength (S) opportunities for business development and marketing for local / traditional food products in this area. But on the other hand, internal factors are also a weakness / Weakness (W) for the business

Internal factors that become Strength (S) strengths include:

a) Availability of Raw Materials. 
Local / traditional food products generally use ingredients that are available in this area so as to produce local food products there is no concern over the scarcity of raw materials. The local / traditional food products observed in this study are Pelleng and Nitak, both of these products are the main raw materials are agricultural products, namely rice and pulut rice. Other ingredients such as: free-range chicken, andaliman, cayenne, red chili, batak onion, and spices (for pelleng supplement). Besides that, many other coconut, brown sugar (for nitak) supplements are available here.

b) Products without preservatives.

Dairi's local / traditional food products are processed without using preservatives so that from the health side, these products are healthier to consume without worries of causing various diseases caused by chemicals used for food preservatives.

c) Strategic location.

Pelleng and nitak are typical foods from Dairi district, Sidikalan is the capital of this district and is a city crossed by people who will go to other regencies in the Lake Toba region and several regencies in the province of Aceh. Sidikalang is a strategic place for the local / traditional food market. Therefore this strategic position is one of the strengths (Strengh) owned by Dairi district.

d) The presence of companion souvenir products.

Dairi Regency is known for its durian and coffee centers and currently this area is also a producer of honey orange which was once popular in Karo District. The companion souvenir product can be a partner for marketing local / traditional food products that are typical of Dairi district.

Internal factors which are weaknesses (Weakness / W) include:

a). Lack of Promotion.

Local / traditional food products kab. Dairi is currently not much promoted either through print / electronic media (radio \& TV) so consumers who want the product will find it difficult to find where the product is always available. This product is generally still traditionally marketed based on orders from consumers. The lack of promotion of this product certainly has an impact on the sale of local / traditional food products.

b) Prices in less competitive markets

Local / traditional foods like pelleng are generally consumed at traditional events, thanksgiving for success and so on. The presentation of the products is also traditionally to be presented in packages for many people. So for the pelleng product itself the price is quite expensive (+ Rp. 250,000 - Rp. 500,000 depending on the combination and size) so that the price is not yet right for the price of souvenirs.

c) Not Long Lasting.

Local / traditional food products such as Pelleng and Nitak are processed without using preservatives. In addition, the process of making and presenting is already mixed for the main product and companion so that the product does not last long / stale quickly. Therefore, this meal after being ready for food must be consumed immediately.

d) At least a variety of products and tastes.

Dairi local / traditional food products that are currently sold like pelleng and nitak lack the variety of products. Like pelleng, for example, generally it has a very spicy taste because it uses cayenne and andaliman pepper. The lack of these variations, of course, for consumers who are less fond of spicy food will retreat regularly to enjoy the meal.

\section{External factors,}

External factors are factors that come from outside the local / traditional food product business. This factor will be an Opportunity (Opportunity) or Challenge (Threats) for local / traditional food product processing businesses in Dairi Regency.

External factors which are Opportunities for business development and marketing for local / traditional food products in this area include:

a) Increasing population

Local / traditional food is dominated by main meals (staples) which are basic needs for the community. The increasing population in the area will be an opportunity for the development of local / traditional food.

b) Development of the internet world

Today's virtual world is becoming a world without borders any product can currently be marketed via the internet, with online patterns. Therefore even this technological progress can be an opportunity for marketing local / traditional food products.

c) Development of the tourism industry.

The tourism industry sector is increasingly developing today, including in the field of culinary tourism. Many traditional food festivals are widely held to boost the growth of culinary tourism. With the development of culinary tourism will be an opportunity for local / traditional food product businesses.

d) Program of the main destination of Lake Toba.

At present the government is launching 10 ungulan destinations in Indonesia, the Lake Toba Region one of them, with 7 regencies in it and Dairi Regency one of them. The program is certainly a great opportunity for districts in the region including Dairi Regency

External factors which constitute the Challenge (Threats) for business development and marketing for local / traditional food products in this area include:

a) The modern lifestyle of the community

The pattern of community life is also a challenge for the development of local / traditional food products, the presence of fast food such as KFC, Mc. Donald, Burger and so on will be able to shift people's lifestyles, especially among teenagers and children.

b) The number of modern food retailers

As explained above, the presence of fast food with more modern retailers will be able to shift local / 
traditional food products. In terms of branding, modern food products are superior to traditional foods, especially in terms of promotion, packaging, cleanliness and others.

c) Number of substitution products.

Local / traditional food products are generally in the form of main courses, but there are still other main foods that can become substitute foods if local / traditional food products are not available. Except for certain events that require local / traditional food to be available. Therefore the presence of substitute foods can be a threat to the existence of local / traditional food products in the future.

From the data above the tabulation of the SWOT analysis can be seen in the following table 4.9 as follows:

Tabel 4.9. Internal and External

\begin{tabular}{ll}
\hline \multicolumn{1}{c}{ Internal Factor } & \multicolumn{1}{c}{ External Factor } \\
\hline \multicolumn{1}{c}{ Strenghtly } & \multicolumn{1}{c}{ Opportunity } \\
a) Availability of Raw Materials. & a) Increasing population \\
b) Products without preservatives. & b) Development of the internet world \\
c) Strategic location. & c) Development of the tourism industry. \\
d) The presence of companion souvenir products. & d) National Program of 10 Leading Tourism Destinations
\end{tabular}

\section{Weakness}

a) Lack of Promotion.

b) Prices in less competitive markets

c) Not Long Lasting.

d) At least a variety of products and tastes.

\section{Treaths}

a) The modern lifestyle of the community

b) The number of modern food retailers

c) Number of substitution products. Source: Research Data 2017

By training the SWOT analysis data above and the existing empirical conditions, a strategy can be developed that can be applied to the local / traditional food product business as follows:

\section{Strategy combines strength with opportunities (Strengths \& Opportunities).}

This strategy is to utilize all the power to seize and take advantage of opportunities as much as possible. With the aim of maintaining the prices that have been set for consumers while always improving product quality to improve and maintain customer satisfaction and loyalty, establish cooperation with potential distributor agents to expand the area of marketing or product distribution, so that it will increase market share. The strategy is carried out, among others by: a) Increase promotion and advertising. Promotional and advertising activities are carried out by adding advertisements in the media, promotion through websites, bonuses for intermediaries (travel drivers, tour buses), and distributing promotional brochures to travel associations (airports, travel, etc.). Promotion through the website is done by creating a personal Blog or through a Facebook account. A bonus for intermediaries is done to attract the interest of intermediaries to bring prospective buyers to the location of the sale. Likewise with the distribution of bonuses to travel associations. This promotional activity aims to introduce products and attract potential buyers from outside the region.

a. Providing incentives to consumers in the form of discounts / discounts. The provision of price incentives for consumers can be done through giving discounts or discounts and giving special discounts. These two price discounts are different. Giving discounts or discounts is intended to reduce the price of a large amount that should be paid by the consumer. This discount can be made for every purchase that occurs. Special discounts are meant for price cuts made at certain times (holidays, certain celebrations, new product launches) or providing special discounted fixed customers and buying lots.

b. Expanding the market. Dairi local / traditional food products have been widely known by the public. Therefore, the product can be expanded in market coverage by adding sub-distributors both inside and outside the area, and expanding the network, by doing business in the form of consignment cooperation.

c. Develop new product attributes with a variety of sizes. Local / traditional food products that have been widely known in the community are generally served in large portions because they are used for the purposes of joint meals (parties) but for purposes in small quantities eg. For daily consumption, it is not yet available, therefore to meet the demand in small quantities it is necessary to attribute new products with various sizes so that in terms of needs and prices can be affordable. 
d. Improve product quality and prices according to market segments. Quality is something that needs to be maintained, so that the products we produce can compete to be marketed. Therefore, despite the size / diversification, the quality of the product must be maintained

2. Strategy to combine opportunities with threats (Strength \& Threathts). This strategy is to use the strength of the company to overcome threats. The strategy that can be used is to create a new product innovation by creating a new form and taste to add new consumers so as to increase product production and sales.

a. Maintain product quality and local product characteristics. As is known quality is the main thing that must be considered, therefore by maintaining the peculiarities of local products and their quality must also be maintained.

b. Improve the quality of service to consumers.Tourism is synonymous with service, if tourists feel satisfied with the services available in a tourist destination it will certainly give their own memories, psychologically, the domino effect that is expected is that tourists will at least be eager to return to the destination at a later time. On the other hand it is expected that tourists will also provide positive information to other families, friends or colleagues so that it will be a means of free promotion by word of mouth of the tourists.

c. Arrangement of outlets with attractive appearance. The layout of the products sold is one of the main interests for consumers to shop, the arrangement of outlets that gives the impression of elegance will provide added value to consumers to buy them.

d. Perform product diversification in accordance with market desires. Each product / service product will have a market saturation point therefore product diversification is worth doing to meet consumers. $\mathrm{z}$ With this, the packaging also gives a distinctive impression to consumers

3. Strategies to combine Weakness with Opportunities :

This strategy is implemented based on the utilization of opportunities that exist by minimizing existing weaknesses. The strategy that can be used is to run a corporate organization management system to facilitate planning, organizing, and controlling the company's operational activities that greatly affect the development of the company and the development of an increasingly modern business world.

a. Make packaging products attractive and practical. One of the weaknesses of local / traditional food products is packaging. Some local / traditional foods that are usually served in traditional ceremonies are products that are difficult to differentiate because they are usually related to adat. Therefore innovation must also pay attention to the local customs / wisdom. However, if packaging innovation does not violate customary rules, packaging should be made as practical and attractive as possible so that consumer interest in the product can be increased.

b. Doing product labeling.The product label is a guarantee of product quality and branding, on the other hand this labeling will make it easier for consumers to search for the product that they once got. Besides this labeling will protect consumers from duplication of less qualified products from competitors. Therefore labeling is needed for local / traditional food products.

c. Expanding sales locations. The market is a producer optimism, with the wider sales location expected to increase sales turnover, which in turn will increase the margin obtained.

d. Expanding marketing networks. The limitations of marketing reach will be one of the obstacles to the development of marketing a product. This condition can be overcome by establishing marketing partnerships with resellers, therefore market networking is needed to increase sales turnover.

e. Providing purchase services between messages. The development of business product marketing is now increasingly varied. Consumers need products and order them with fingertips. Therefore this phenomenon must be addressed properly. One effort to provide the best servants to consumers is through inter-service orders. So that consumers no longer have to bother having to leave the house if they want a type of product.

\section{Strategy combines weaknesses with} threats

This strategy is based on company activities that are defensive and try to 
minimize existing weaknesses and avoid threats (Threathts) owned by the company. Strategies that can be done are:

a. Maintain cleanliness of products and packaging. The cleanliness of products and packaging is one of the concerns for consumers. This will provide a sense of security for consumers to consume local / traditional food products that we market,

b. Setting affordable prices by not reducing quality. One of the ways to attract consumers to marketed products is by offering affordable and more competitive prices. But cheap price offers must also pay attention to the quality of the product is maintained. c. Develop a joint venture (Joint Venture) with those who provide capital. Business development through own capital will be more quickly realized because it does not have to wait for a complicated process or agreement with cooperation partners. However, this will be constrained if the availability of funds or working capital is inadequate. One solution that is not carried out is by means of joint ventures, so that the need for business capital will be fulfilled in accordance with the availability of funds.

A number of these strategies when described in the form of tables will look as follows:

Table 4.10 Formula of Product Marketing Development strategy

Dairi Local / traditional food

\begin{tabular}{|c|c|c|}
\hline External Factor & $\begin{array}{l}\text { Strength (S) : } \\
\text { a) Availability of Raw Materials. } \\
\text { b) Products without preservatives. } \\
\text { c) Strategic location. } \\
\text { d) The presence of companion } \\
\text { souvenir products. }\end{array}$ & $\begin{array}{l}\text { Weaknes (W) } \\
\text { a) Lack of Promotion. } \\
\text { b) Prices in less competitive markets } \\
\text { c) Not Long Lasting. } \\
\text { d) At least a variety of products and } \\
\text { tastes. }\end{array}$ \\
\hline $\begin{array}{l}\text { Opportunities }(\boldsymbol{O}) \\
\text { a) Increasing population } \\
\text { b) Development of the internet world } \\
\text { c) Development of the tourism } \\
\text { industry. } \\
\text { d) National Program of } 10 \text { Leading } \\
\text { Tourism Destinations }\end{array}$ & $\begin{array}{l}\text { Strategi SO } \\
\text { a) Increase promotion and advertising } \\
\text { b) Providing incentives to consumers } \\
\text { in the form of discounts / discounts } \\
\text { c) Expanding the market } \\
\text { d) Develop new product attributes } \\
\text { with a variety of sizes. }\end{array}$ & $\begin{array}{l}\text { Strategi SW } \\
\text { a) Make packaging products } \\
\text { attractive and practical } \\
\text { b) Perform product labeling } \\
\text { c) Expanding sales locations } \\
\text { d) Expanding marketing networks } \\
\text { e) Providing purchase services } \\
\text { between messages. }\end{array}$ \\
\hline $\begin{array}{l}\text { Threats } \\
\text { a) The modern lifestyle of the } \\
\text { community } \\
\text { b) The number of modern food } \\
\text { retailers } \\
\text { c) Number of substitution products }\end{array}$ & $\begin{array}{l}\text { Strategi ST } \\
\text { a) Maintain product quality and local } \\
\text { product characteristics. } \\
\text { b) Improve the quality of service to } \\
\text { consumers. } \\
\text { c) Arrangement of outlets with } \\
\text { attractive appearance } \\
\text { d) Perform product diversification in } \\
\text { accordance with market desires. }\end{array}$ & $\begin{array}{l}\text { Strategi TW } \\
\text { a) Maintain cleanliness of products } \\
\text { and packaging } \\
\text { b) Set affordable prices without } \\
\text { reducing quality } \\
\text { c) Develop a joint venture (Joint } \\
\text { Venture) with parties providing } \\
\text { capital.b }\end{array}$ \\
\hline
\end{tabular}

Source: Research Data 2017

\section{CONCLUSION}

From the results of the discussion in the previous chapter it can be concluded that:

a. People in Dairi Regency, especially local / traditional food producers, restaurant managers and culinary activists do not yet have the readiness to make local / traditional food as a typical gift of Dairi Regency to support the development of tourist destinations in Dairi Regency b. The prospect of the local food industry business as a typical souvenir of Dairi Regency is basically quite good, especially Dairi district is currently included in the Lake Toba Region which is an area that will be developed by the government as a leading tourism destination in Indonesia. But culinary actors in this area still have not responded well to these conditions.

c. The economic impact for the community from the local / traditional food industry business as a typical 
gift in Dairi Regency has not been seen as significant because the community is still not much involved in the tourism sector business, even though in certain destinations there have been many SMEs involved.

\section{Suggestion}

From the conclusions above the suggestions that can be given are as follows:

a. People in Dairi Regency, especially local / traditional food producers, restaurant managers and culinary activists in this area need to be enlightened / educated about how to prepare local / traditional food as a typical gift of Dairi Regency to support the development of tourist destinations in the Regency Dairi

b. It is necessary to provide an understanding to the community in this area, especially culinary actors, that the business prospects of the local food industry as a typical gift of Dairi Regency are basically quite good, moreover Dairi Regency is currently included in the Lake Toba Region which is an area to be developed by the government as a leading tourism destination in Indonesia through conscious travel or training activities organized by relevant agencies / institutions.

c. In order to socialize the tourism sector as a multiplier effect, it needs to be shaped or re-activated by a conscious group that will be the spearhead in the community for the development of the tourism sector, specifically for culinary actors in this area.

\section{REFERENCES}

Aan Komariah dan Djam'an Satori (2010) Metodologi Penelitian Kualitatif Bandung : Alfabeta.

Alteza, Muniya (2014) Pengembangan Bisnis Produk Makanan Tradisional, FE UNY, Yogjakarta

Arikunto, S (2008) Prosedur penelitian suatu pendekatan praktek, Bandung: Alpabeta.

Chresy dkk, (2012) Strategi Pengembangan Pemasaran Makanan Khas Bengkulu Pada Sentra Oleh-Oleh Anggut Kota Bengkulu: Aplikasi Ahp Dan Swot, Jurnal Arisep Vol 11 No. 2 Hal 204-219.
Clarke J dan Godfrey K (2000) The Tourism Development Handbook: A Practical Approach To Planning and Marketing. Continuum, London.

David, Fred R (2010) Strategic Management. Manajemen Strategis. Edisi Keduabelas, Buku Satu. Jakarta: Salemba Empat.

Freddy Rangkuti (2001) Analisis SWOT Teknik Membedah Kasus Bisnis. Jakarta. PT. Gramedia Pustaka Utama.

Hìdayat, A. (2007). Strategi six sigma: Peta pengembangan kualitas dan kinerja bisnis. Jakarta: Elex Media Komputindo.

Hidayat, Maceilla. (2011) Strategi Perencanaan Dan Pengembangan Objek Wisata (Kasus Pantai Pangandaran Kabupaten Ciamis Jawa Barat), Jurnal Tourism and Hospitality Essentials (THE), Vol I No.1 2011

Jessica, Kwik (2008) Traditional Food Knowledge: A Case Study of an Immigrant Canadian "Foodscape" Environments: a journal of interdisciplinary studies/revue d'études interdisciplina

Kotler, Philip. dan Armstrong, Gary (2008) Prinsipprinsip pemasaran. Jilid 1. Edisi Keduabelas. Jakarta: Erlangga.

Rahmady, Radiany dan Andi, Sularso (2007) Konsentrasi Pemasarar Curnhora: Badan Penerbit Mahardhika.

Rahman, Fadly (2016) Jeja isantara: Sejarah Makanan Indonesia, Jakarta: Úramedia Pustaka Utama

Ritonga, Abdul Kadir (2018) Program Development as an Alternative Improvement of Service Quality and Results of Vocational Education. International Journal of Social Sciences and Educational Studies. 4 (4), 22-26

Sugiyono (2012). Metode Penelitian Kuantitatif dan Kualitatif. Bandung: CV.Alfabeta.

Undang-Undang Pariwisata No. 10 Tahun 2009 tentang Kepariwisataan, Jakarta. 